(c) American Dairy Science Association, 2004.

\title{
Dietary Cation-Anion Difference Effects on Performance and Acid-Base Status of Lactating Dairy Cows: A Meta-Analysis*
}

\author{
W. Hu and M. R. Murphy \\ Department of Animal Sciences, University of Illinois, Urbana 61801
}

\section{ABSTRACT}

A meta-analysis was conducted to examine potential empirical relationships between dietary cation-anion difference $(\mathrm{DCAD})(\mathrm{Na}+\mathrm{K}-\mathrm{Cl})$ and the response of lactating dairy cows. The database was developed from 12 studies published between 1984 and 1997 that included a total of 17 trials, 69 dietary treatments, and 230 cows. Results indicated that DCAD affected performance of lactating dairy cows. Maximum milk yield and feed intake were reached when DCAD was 34 and $40 \mathrm{meq} / 100 \mathrm{~g}$ of feed dry matter, respectively. Blood $\mathrm{pH}$ and $\mathrm{HCO}_{3}$ concentrations increased with DCAD, indicating an improved acid-base balance of lactating dairy cows. Changes in urinary $\mathrm{pH}$ and urinary excretion of $\mathrm{Na}, \mathrm{K}$, and $\mathrm{Cl}$ were consistent with varying DCAD, thus dietary acidity or alkalinity. The effects of DCAD were likely mediated via modification of acidbase status in the cows.

(Key words: dietary cation-anion difference, acid-base status, dairy cow, meta-analysis)

Abbreviation key: DCAD = dietary cation-anion difference, $\mathbf{B C A D}=$ blood cation-anion difference, $\mathbf{p} \mathbf{C O}_{2}=$ blood $\mathrm{CO}_{2}$ partial pressure.

\section{INTRODUCTION}

Major effects of dietary cation-anion difference (DCAD; defined as milliequivalents of $\mathrm{Na}+\mathrm{K}-\mathrm{Cl}$ per 100 grams of feed DM) on animal performance are thought to be linked with acid-base regulation. The concept of manipulating dietary cation-anion balance is not new; its relationship to acid-base status and overall production has been investigated thoroughly and is well established in nonruminants (Austic and Patience, 1988). In cattle, much work has been done with prepartum cows on the role of DCAD for prevention of parturi-

Received August 22, 2003.

Accepted January 20, 2004.

Corresponding author: M. R. Murphy; e-mail: mrmurphy@ uiuc.edu.

*Supported by Illinois Agricultural Experiment Station, RRF 35309 NE-132. ent paresis. Diets with negative DCAD reduced its incidence (Block, 1984; Oetzel et al., 1988). With the increased use of the DCAD concept in dry-cow nutrition, interest has also grown in the potential effects of DCAD on lactating dairy cows. Some studies have suggested that there could be an optimal DCAD for maximizing feed consumption and milk yield (Sanchez and Beede, 1996; Block and Sanchez, 2000). Unfortunately, evidence has emerged that parameters in equations describing these relationships can be estimated with considerable bias if mixed effects statistical models are not used (St-Pierre, 2001). The DCAD and productivity might be related, but a properly conducted meta-analysis of available data is needed to re-examine this issue quantitatively. Analyses reported herein are based on data collated from studies of lactating dairy cows fed different DCAD in totally mixed diets. Our objective was to examine potential empirical relationships between DCAD and the performance and acid-base balance of lactating dairy cows.

\section{MATERIALS AND METHODS}

\section{Database}

Twelve studies (Escobosa et al., 1984; Tucker et al., 1988a,b; McKinnon et al., 1990; Waterman et al., 1991; Tucker et al., 1991, 1994; West et al., 1991, 1992; Delaquis and Block, 1995a,b; Sanchez et al., 1997) met our criteria for use; they reported results for varying DCAD or buffer (with sodium, potassium, and chloride contents measured that enabled calculation of DCAD) effects on lactating dairy cows. Data of Roche et al. (2003) were excluded because salts to change DCAD were not included in totally mixed diets but were administered by gavage.

Data from 17 trials, 69 feeding treatments, and 230 cows were included. Over $90 \%$ of the data were from Holstein cow records. Forage types were mainly corn silage and alfalfa silage, and at least $30 \%$ forage was included in totally mixed diets (Table 1 ). Delaquis and Block (1995a,b) measured blood parameters prefeeding and 2 and $4 \mathrm{~h}$ postfeeding. Prefeeding values were used in this analysis. 
Table 1. Brief summary of studies included in the database.

\begin{tabular}{|c|c|c|c|c|c|}
\hline Study no. & Trial no. & $\begin{array}{l}\text { Diet } \\
\text { (no.) }\end{array}$ & $\begin{array}{l}\text { Breed } \\
\text { (no. of cows) }\end{array}$ & $\begin{array}{l}\text { Forage type } \\
(\% \text { of dietary DM) }\end{array}$ & Reference \\
\hline 1 & 1 & 2 & $\begin{array}{l}\text { Holstein (10) } \\
\text { Ayrshire (2) }\end{array}$ & $\begin{array}{l}\text { Corn silage }(50 \%) \text {, and } \\
\text { Alfalfa silage }(10 \%) \text { vs. } \\
\text { Alfalfa silage }(55 \%)\end{array}$ & $\begin{array}{l}\text { Delaquis and Block } \\
\text { (1995a) }\end{array}$ \\
\hline \multirow[t]{2}{*}{2} & 1 & 2 & Holstein (12) & Alfalfa silage (51\%) & \multirow[t]{2}{*}{$\begin{array}{l}\text { Delaquis and Block } \\
(1995 \mathrm{~b})\end{array}$} \\
\hline & $\begin{array}{l}2 \\
3\end{array}$ & $\begin{array}{l}2 \\
2\end{array}$ & $\begin{array}{l}\text { Holstein (12) } \\
\text { Holstein (12) }\end{array}$ & $\begin{array}{l}\text { Alfalfa silage }(49 \%) \\
\text { Alfalfa silage }(56 \%)\end{array}$ & \\
\hline 3 & 1 & 3 & $\begin{array}{l}\text { Holstein (12) } \\
\text { Jersey (12) }\end{array}$ & $\begin{array}{l}\text { Corn silage }(33 \%) \text { and } \\
\text { Cottonseed hulls (6 to } 8 \%)\end{array}$ & Escobosa et al. (1984) \\
\hline 4 & 1 & 4 & Holstein (4) & Barley $(67 \%)$ & McKinnon et al. (1990) \\
\hline 5 & 1 & 8 & Holstein (36) & Corn silage $(40 \%)$ & Sanchez et al. (1997) \\
\hline 6 & 1 & 12 & Holstein (12) & Corn silage (50\%) & Tucker et al. (1988a) \\
\hline 7 & 1 & 2 & Holstein (8) & Corn silage $(46 \%)$ & Tucker et al. (1988b) \\
\hline 8 & $\begin{array}{l}1 \\
2\end{array}$ & $\begin{array}{l}5 \\
5\end{array}$ & $\begin{array}{l}\text { Holstein (5) } \\
\text { Holstein (5) }\end{array}$ & $\begin{array}{l}\text { Corn silage }(48 \%) \\
\text { Sorghum silage }(39 \%)\end{array}$ & Tucker et al. (1991) \\
\hline 9 & 1 & 2 & Holstein (48) & $\begin{array}{l}\text { Alfalfa hay }(13 \%) \text { and } \\
\text { Sorghum silage }(18 \%)\end{array}$ & Tucker et al. (1994) \\
\hline 10 & 1 & 4 & Holstein (8) & Corn silage $(35 \%)$ & Waterman et al. (1991) \\
\hline \multirow[t]{2}{*}{11} & 1 & 4 & $\begin{array}{l}\text { Holstein (4) } \\
\text { Jersey (4) }\end{array}$ & Corn silage $(40 \%)$ & \multirow[t]{2}{*}{ West et al. (1991) } \\
\hline & 2 & 4 & $\begin{array}{l}\text { Holstein (4) } \\
\text { Jersey (4) }\end{array}$ & Corn silage (40\%) & \\
\hline \multirow[t]{2}{*}{12} & 1 & 4 & Holstein (8) & Corn silage (40\%) & \multirow[t]{2}{*}{ West et al. (1992) } \\
\hline & 2 & 4 & Holstein (8) & Corn silage $(40 \%)$ & \\
\hline
\end{tabular}

Tucker et al. (1991) conducted 2 trials that explored the role of sulfur and chloride in DCAD for lactating dairy cows. Although DCAD was formulated to be identical in the 2 trials, only the measured DCAD values of their first trial were used in present study to examine the relationships between dependent variables and DCAD.

Some records were incomplete or not reported uniformly, which necessitated the following assumptions and calculations. With the exception of one study (Escobosa et al., 1984), all blood mineral concentrations were consistently measured in either plasma or serum; however, all such data were pooled for analysis and considered as blood contents of these minerals. Urine mineral data from 2 studies in which urine output was measured were expressed relative to urine creatinine for comparison with those of 6 other studies that had reported their data on this basis but not quantified urine output. Two studies specified that total milk protein was measured; however, the remainder reported only milk protein. In the absence of detailed information in the original references, the more general term milk protein was used even though it is not as precise. Mean, standard deviation, and minimal and maximal values for all major selected variables are presented in Table 2 .

\section{Statistical Analysis}

In all studies, treatment means of DMI, milk yield, blood $\mathrm{pH}$, blood bicarbonate, blood $\mathrm{CO}_{2}$ partial pressure $\left(\mathbf{p} \mathbf{C O}_{2}\right)$, blood mineral contents, urine $\mathrm{pH}$, and urine minerals were used to examine the overall effect of DCAD across studies. Potential relationships between these dependent variables and DCAD, blood cationanion difference (BCAD, in milliequivalents of $\mathrm{Na}+\mathrm{K}$ $-\mathrm{Cl}$ per L of blood), or dietary minerals (Table 3) were investigated using the PROC MIXED model procedures in the SAS system (2001). The model was

$$
\mathrm{Y}_{\mathrm{ij}}=\mathrm{B}_{0}+\mathrm{B}_{1} \mathrm{X}_{\mathrm{ij}}+\mathrm{B}_{2} \mathrm{X}_{\mathrm{ij}}{ }^{2}+\mathrm{s}_{\mathrm{i}}+\mathrm{b}_{1 \mathrm{i}} \mathrm{X}_{\mathrm{ij}}+\mathrm{b}_{2 \mathrm{i}} \mathrm{X}_{\mathrm{ij}}{ }^{2}+\mathrm{e}_{\mathrm{ij}}
$$

where

$$
\begin{aligned}
\mathrm{i} & =1,2, \ldots, 12 \text { studies; } \\
\mathrm{j} & =1,2, \ldots, \mathrm{n}_{\mathrm{i}} \text { observations within study } \mathrm{i} ; \\
\mathrm{B}_{0}= & \text { overall intercept across studies (fixed ef- } \\
& \text { fect); }
\end{aligned}
$$

$\mathrm{B}_{1}$ and $\mathrm{B}_{2}=$ parameter estimates for the linear and quadratic terms of the polynomial function across studies (fixed effects);

$X_{i j}=$ value of variable $X$ for observation $j$ in study i;

$\mathrm{s}_{\mathrm{i}}=$ random intercept effect of study $\mathrm{i}$;

$b_{1 i}$ and $b_{2 i}=$ parameter estimates for the linear and quadratic terms of the polynomial function in study i (random effects); and

$$
\mathrm{e}_{\mathrm{ij}}=\text { error term, assumed } \mathrm{N}\left(0, \sigma^{2}\right) \text {. }
$$

Study was considered a random effect (St-Pierre, 2001). Full models containing linear and quadratic terms were 
HU AND MURPHY

Table 2. Mean and range of dietary cation-anion difference (DCAD) and selected variables in the database.

\begin{tabular}{|c|c|c|c|c|c|}
\hline Factor & Mean & No. & SD & Minimum & Maximum \\
\hline $\mathrm{DCAD}, \mathrm{meq} / 100 \mathrm{~g}$ of DM & 26.13 & 69 & 19.43 & -19.10 & 63.57 \\
\hline \multicolumn{6}{|l|}{ Diet } \\
\hline $\mathrm{Na}, \%$ of $\mathrm{DM}$ & 0.39 & 69 & 0.21 & 0.10 & 1.16 \\
\hline $\mathrm{K}, \%$ of $\mathrm{DM}$ & 1.19 & 69 & 0.44 & 0.28 & 2.23 \\
\hline $\mathrm{Cl}, \%$ of $\mathrm{DM}$ & 0.79 & 69 & 0.41 & 0.21 & 1.65 \\
\hline $\mathrm{Ca}, \%$ of $\mathrm{DM}$ & 0.78 & 69 & 0.19 & 0.54 & 1.31 \\
\hline $\mathrm{P}, \%$ of DM & 0.42 & 69 & 0.08 & 0.21 & 0.56 \\
\hline $\mathrm{Mg}, \%$ of $\mathrm{DM}$ & 0.34 & 69 & 0.12 & 0.20 & 0.66 \\
\hline $\mathrm{S}, \%$ of $\mathrm{DM}$ & 0.33 & 38 & 0.18 & 0.11 & 0.91 \\
\hline $\mathrm{CP}, \%$ of $\mathrm{DM}$ & 16.30 & 69 & 1.33 & 13.90 & 18.90 \\
\hline $\mathrm{NE}_{\mathrm{L}}, \mathrm{Mcal} / \mathrm{kg}$ of $\mathrm{DM}$ & 1.66 & 38 & 0.09 & 1.52 & 1.81 \\
\hline $\mathrm{NDF}, \%$ of DM & 38.54 & 38 & 6.85 & 26.90 & 53.50 \\
\hline $\mathrm{ADF}, \%$ of $\mathrm{DM}$ & 21.66 & 61 & 3.06 & 16.00 & 27.80 \\
\hline DMI, kg/d & 18.41 & 54 & 2.65 & 10.70 & 22.68 \\
\hline \multicolumn{6}{|l|}{ Milk } \\
\hline Yield, kg/d & 22.98 & 54 & 5.30 & 14.90 & 35.96 \\
\hline $4 \% \mathrm{FCM}, \mathrm{kg} / \mathrm{d}$ & 21.61 & 54 & 3.87 & 14.87 & 30.78 \\
\hline Fat, \% & 3.68 & 54 & 0.42 & 2.60 & 4.41 \\
\hline Fat yield, kg/d & 0.83 & 54 & 0.13 & 0.55 & 1.16 \\
\hline Protein, \% & 3.18 & 54 & 0.20 & 2.63 & 3.50 \\
\hline Protein yield, kg/d & 0.74 & 54 & 0.18 & 0.43 & 1.18 \\
\hline \multicolumn{6}{|l|}{ Blood } \\
\hline $\mathrm{pH}$ & 7.399 & 56 & 0.053 & 7.308 & 7.500 \\
\hline Bicarbonate, meq/L & 25.58 & 56 & 3.23 & 17.30 & 30.95 \\
\hline $\mathrm{pCO}_{2}, \mathrm{~mm}$ of $\mathrm{Hg}$ & 42.01 & 56 & 6.77 & 30.57 & 53.64 \\
\hline Base excess, meq/L & 0.61 & 34 & 2.66 & -6.76 & 4.60 \\
\hline $\mathrm{Na}, \mathrm{meq} / \mathrm{L}$ & 140.75 & 46 & 8.77 & 123.75 & 161.50 \\
\hline $\mathrm{K}, \mathrm{meq} / \mathrm{L}$ & 5.05 & 46 & 0.94 & 3.65 & 7.30 \\
\hline $\mathrm{Cl}, \mathrm{meq} / \mathrm{L}$ & 101.09 & 46 & 3.68 & 87.37 & 107.80 \\
\hline $\mathrm{Ca}, \mathrm{mg} / \mathrm{dL}$ & 9.90 & 42 & 0.79 & 8.58 & 11.43 \\
\hline $\mathrm{Mg}, \mathrm{mg} / \mathrm{dL}$ & 2.37 & 42 & 0.43 & 1.58 & 3.34 \\
\hline $\mathrm{P}, \mathrm{mg} / \mathrm{dL}$ & 6.46 & 32 & 1.65 & 2.94 & 9.60 \\
\hline \multicolumn{6}{|l|}{ Urine } \\
\hline $\mathrm{Na}^{1}$ & 3.10 & 39 & 1.38 & 0.21 & 6.74 \\
\hline $\mathrm{K}^{1}$ & 8.20 & 39 & 6.24 & 1.20 & 29.64 \\
\hline $\mathrm{Cl}^{1}$ & 8.99 & 39 & 14.11 & 0.08 & 53.16 \\
\hline $\mathrm{pH}$ & 7.537 & 46 & 0.957 & 5.380 & 8.646 \\
\hline
\end{tabular}

${ }^{1}$ Expressed as urine mineral:creatinine ratio.

reduced by removing terms that did not contribute significantly to the model via the stepwise, backward procedure. Dependent variables were not weighted. Significance was declared at $P<0.1$ unless otherwise noted.

Table 3. Major variables in regression analysis using the mixed effects model.

\begin{tabular}{ll}
\hline Independent variable & Dependent variable \\
\hline $\mathrm{DCAD},{ }^{1} \mathrm{meq} / 100 \mathrm{~g}$ of $\mathrm{DM}$ & $\mathrm{DMI}, \mathrm{kg} / \mathrm{d}$ \\
& Milk yield, $\mathrm{kg} / \mathrm{d}$ \\
& $4 \% \mathrm{FCM}, \mathrm{kg} / \mathrm{d}$ \\
& $\mathrm{Blood}$ \\
& $\mathrm{HCO}_{3}, \mathrm{meq} / \mathrm{L}$ \\
& $\mathrm{pH}$ \\
& $\mathrm{pCO}_{2}, \mathrm{~mm}$ of $\mathrm{Hg}$ \\
& minerals, meq/L \\
& Urine $\mathrm{pH}$ \\
& Blood minerals, meq/L \\
Dietary minerals, $\%$ of $\mathrm{DM}$ & Urine minerals, \\
& mineral:creatinine ratio
\end{tabular}

${ }^{1} \mathrm{DCAD}=$ dietary cation-anion difference.
In a mixed effects model, there are both fixed (intercept and slope) and random (intercept and slope) effects for independent variables. The intercept and slope of the fixed effect in the mixed model represent a mean intercept and a mean slope for the response to DCAD or other independent variables. Regression curves are presented based on predicted values of dependent variables vs. DCAD; whereas, adjusted observations across studies are also plotted to indicate trends of dependent variables vs. DCAD.

The random study effect represents the variance among studies not accounted for by other variables in the model that had been shown important in regression analysis (St-Pierre, 2001). When presenting results of mixed model analyses graphically in 2 dimensions, the $\mathrm{Y}$ observations must be adjusted for the additional 12 dimensions represented by individual studies. Adjusted observations for study effects were also used to calculate coefficients of multiple determination $\left(\mathrm{R}^{2}\right)(\mathrm{St}$ Pierre, 2001). 


\section{RESULTS AND DISCUSSION}

\section{Lactation Performance}

Milk yield increased quadratically $\left(P=0.002 ; \mathrm{R}^{2}=\right.$ 0.49 ) with DCAD, peaking at $34 \mathrm{meq} / 100 \mathrm{~g}$ of DM (Table 4; Figure 1). The standard error for peak milk yield, estimated based on 200 bootstrap replications (Efron, 1982), was $0.7 \mathrm{meq} / 100 \mathrm{~g}$ of DM. Cows also yielded (quadratic, $P=0.029 ; \mathrm{R}^{2}=0.59$ ) more $4 \% \mathrm{FCM}$ as DCAD increased to $49 \mathrm{meq} / 100 \mathrm{~g}$ of DM (Table 4; Figure 2).

A quadratic $\left(P<0.001 ; \mathrm{R}^{2}=0.80\right)$ effect of DCAD on DMI suggested that consumption peaked at a DCAD of $40 \mathrm{meq} / 100 \mathrm{~g}$ of DM (Table 4; Figure 3 ). The standard error for peak DMI, estimated by the same technique as for peak milk yield, was $0.4 \mathrm{meq} / 100 \mathrm{~g}$ of DM. Depressed feed intake when DCAD was low, especially when DCAD was negative, may be related to palatability of the anionic salt source or metabolic acidosis resulting from an increase of dietary anions. The DCAD is usually decreased by adding $\mathrm{CaCl}_{2}$ as a $\mathrm{Cl}$ source; palatability of $\mathrm{CaCl}_{2}$-supplemented diets may play a role in depression of feed intake (Tucker et al., 1988a; West et al., 1991, 1992). Huber (1976) indicated that acidosis reduced the feed intake of steers, a response linked with decreased blood $\mathrm{HCO}_{3}$. Quadratic relationships of DCAD with blood $\mathrm{pH}\left(P<0.001 ; \mathrm{R}^{2}=0.83\right)$ and $\mathrm{HCO}_{3}$ $\left(P<0.001 ; \mathrm{R}^{2}=0.88\right)$ in the present study, peaking at DCAD of 35 and $47 \mathrm{meq} / 100 \mathrm{~g}$ of DM, respectively (Table 4; Figures 4 and 5), are consistent with these observations.

Milk fat percentage was unaffected by DCAD, whereas, milk fat yield increased quadratically $(P=$ 0.053 ) with DCAD to a peak at $55 \mathrm{meq} / 100 \mathrm{~g}$ of DM (Table 4). There was no effect of DCAD on milk protein percentage; however, milk protein yield increased quadratically $(P=0.012)$ with DCAD, peaking at 40 meq/ $100 \mathrm{~g}$ of DM. The effects of DCAD on milk fat and protein yields resulted primarily from its effect on milk yield.

Numerous studies have shown that addition of dietary buffers increases milk fat percentage when milk fat was depressed. Supplementation of buffers, such as $\mathrm{NaHCO}_{3}$, increases DCAD. Moreover, milk fat percentage is positively related to the ruminal $\mathrm{pH}$ (Allen, 1997) and is considered to reflect the adequacy of ruminal $\mathrm{pH}$ and effective NDF (Kolver et al., 2002). It is reasonable then to hypothesize that increased DCAD resulting from addition of buffers might play some role in alleviating milk fat depression via acid-base regulation. Milk fat percentage as a dependent variable was of particular interest in this study; however, $90 \%$ of treatment means for milk fat percentage in the database were $\geq 3.3 \%$. This made it unlikely that we would have detected an overall effect of DCAD on milk fat percentage. Addition- ally, the effect of DCAD on milk fat percentage is difficult to assess because multiple factors are involved in milk fat synthesis. Moderate to high forage diets in this database (Table 1) were apparently adequate to maintain normal milk fat percentage in most cases. The dilution effect of increased milk yield may also help explain why milk fat percentage was not directly affected by DCAD.

The NRC (2001) Na, K, and Cl recommendations for lactating cows are $0.19,1.02$, and $0.25 \%$ of $\mathrm{DM}$, respectively, resulting in a DCAD of $27 \mathrm{meq} / 100 \mathrm{~g}$ of DM. Milk yield, 4\% FCM yield, and DMI in the present study were maximal at 34,49 , and $40 \mathrm{meq} / 100 \mathrm{~g}$ of DM, respectively. Current recommendations may not maximize productivity. Block and Sanchez (2000) indicated that DCAD was a more important determinant of dietary impact on systemic acid-base status than actual dietary concentrations of $\mathrm{Na}, \mathrm{K}$, and $\mathrm{Cl}$; therefore, DCAD should be considered in formulating diets for lactating dairy cows. Sanchez and Beede (1996) suggested that the optimal DCAD for lactation ranged between 25 and 50 meq/100 g of DM; milk yield, $4 \%$ FCM yield, and DMI all peaked at a DCAD of 38 meq/100 g of DM based on their general linear model analysis of data from 10 studies. Our mixed-model analysis indicated that $4 \%$ FCM yield did not peak until the higher end of the 25 - to 50 -meq/100 $\mathrm{g}$ of DM range was reached. Our results showed that milk yield, $4 \%$ FCM yield, and DMI were maximized when DCAD was in the somewhat narrower range of 34 to $49 \mathrm{meq} / 100 \mathrm{~g}$ of DM. Diets fed to high yielding dairy cows should be monitored to ensure that DCAD is in this range.

\section{Blood Acid-Base Status}

Blood $\mathrm{pH}$ values (Table 2) were within the normal range of 7.27 to 7.49 (Swenson, 1993). This was expected because maintaining blood $\mathrm{pH}$ is critical to normal body function, a principal goal of homeostatic mechanisms buffering changes in acidity or alkalinity. As previously discussed, blood $\mathrm{pH}$ and $\mathrm{HCO}_{3}$ both increased quadratically, peaking at 35 and $47 \mathrm{meq} / 100 \mathrm{~g}$ of DM, respectively, reflecting increased alkalinity of the diets. The blood $\mathrm{HCO}_{3}$ pattern likely explains the blood $\mathrm{pH}$ response. Based on the Henderson-Hasselbach equation [blood $\mathrm{pH}=6.1+\log _{10}\left(\mathrm{HCO}_{3} /(0.03 \times\right.$ $\left.\mathrm{pCO}_{2}\right)$, alterations in blood $\mathrm{HCO}_{3}$ or blood $\mathrm{pCO}_{2}$ have an immediate effect on blood $\mathrm{pH}$. In addition, blood $\mathrm{pCO}_{2}$ increased linearly with $\mathrm{DCAD}\left(P=0.004 ; \mathrm{R}^{2}=\right.$ 0.35 ; Table 4 ), indicating that there was respiratory compensation for the changes in blood $\mathrm{HCO}_{3}$ concentration.

Blood $\mathrm{pH}$ and $\mathrm{HCO}_{3}$ increased linearly $(P<0.001$; $\mathrm{R}^{2}=0.72$ and $P<0.001 ; \mathrm{R}^{2}=0.85$, respectively) with 
Table 4. Regression relationships $(P<0.100)$ inferred using mixed effects models. ${ }^{1}$

\begin{tabular}{|c|c|c|c|c|c|c|c|c|c|c|c|c|c|}
\hline $\begin{array}{l}\text { Dependent } \\
\text { variable }\end{array}$ & $\begin{array}{l}\text { Independent } \\
\text { variable }\end{array}$ & No. & Intercept & SE & $P$ & Linear & SE & $P$ & Quadratic & SE & $P$ & $\begin{array}{l}\text { Residual } \\
\text { SE }\end{array}$ & $\mathrm{R}^{2}$ \\
\hline $\begin{array}{l}\text { DMI } \\
\text { Milk }\end{array}$ & DCAD & 54 & 16.49 & 0.69 & $<0.001$ & 0.1590 & 0.0170 & $<0.001$ & -0.00201 & 0.00038 & $<0.001$ & 0.850 & 0.80 \\
\hline \multicolumn{14}{|l|}{ Milk } \\
\hline $4 \% \mathrm{FCM}$ & DCAD & 54 & 20.66 & 1.28 & $<0.001$ & 0.0998 & 0.0202 & $<0.001$ & -0.00102 & 0.00045 & 0.029 & 1.006 & 0.59 \\
\hline Fat yield & DCAD & 54 & 0.74 & 0.03 & $<0.001$ & 0.0055 & 0.0009 & $<0.001$ & -0.00005 & 0.00002 & 0.053 & 0.052 & 0.63 \\
\hline Protein yield & DCAD & 54 & 0.74 & 0.06 & $<0.001$ & 0.0032 & 0.0007 & $<0.001$ & -0.00004 & 0.00002 & 0.012 & 0.033 & 0.51 \\
\hline \multicolumn{14}{|l|}{ Blood } \\
\hline $\mathrm{pH}$ & DCAD & 54 & 7.365 & 0.017 & $<0.001$ & 0.0028 & 0.0002 & $<0.001$ & -0.00004 & 0.00001 & $<0.001$ & 0.012 & 0.83 \\
\hline $\mathrm{HCO}_{3}$ & DCAD & 54 & 23.43 & 0.78 & $<0.001$ & 0.1721 & 0.0152 & $<0.001$ & -0.00184 & 0.00034 & $<0.001$ & 0.757 & 0.88 \\
\hline $\mathrm{pCO}_{2}$ & DCAD & 54 & 41.27 & 2.01 & $<0.001$ & 0.0474 & 0.0153 & 0.004 & & & & 1.284 & 0.35 \\
\hline $\mathrm{pH}$ & BCAD & 46 & 7.218 & 0.051 & $<0.001$ & 0.0043 & 0.0010 & $<0.001$ & & & & 0.023 & 0.72 \\
\hline $\mathrm{HCO}_{3}$ & BCAD & 46 & 9.91 & 3.13 & 0.013 & 0.3383 & 0.0602 & $<0.001$ & & & & 1.226 & 0.85 \\
\hline $\mathrm{K}$ & DCAD & 46 & 5.09 & 0.36 & $<0.001$ & -0.0048 & 0.0020 & 0.022 & & & & 0.162 & 0.26 \\
\hline $\mathrm{Cl}$ & Dietary Cl & 46 & 97.09 & 1.22 & $<0.001$ & 4.9276 & 1.1708 & $<0.001$ & & & & 2.704 & 0.37 \\
\hline $\mathrm{Cl}$ & DCAD & 46 & 103.43 & 1.24 & $<0.001$ & -0.1845 & 0.0511 & 0.001 & 0.00247 & 0.00111 & 0.032 & 2.617 & 0.36 \\
\hline $\mathrm{P}$ & Dietary P & 32 & -44.37 & 16.74 & 0.045 & 202.38 & 68.5195 & 0.042 & -197.38000 & 68.97400 & 0.046 & 0.455 & 0.85 \\
\hline $\mathrm{Mg}$ & DCAD & 42 & 2.37 & 0.17 & -0.001 & 0.0077 & 0.0031 & 0.018 & -0.00016 & 0.00007 & 0.027 & 0.141 & 0.24 \\
\hline \multicolumn{14}{|l|}{ Urine } \\
\hline $\mathrm{pH}$ & DCAD & 46 & 6.272 & 0.146 & $<0.001$ & 0.0716 & 0.0075 & $<0.001$ & -0.00058 & 0.00015 & $<0.001$ & 0.401 & 0.86 \\
\hline $\mathrm{Na}$ & Dietary Na & 39 & 0.20 & 0.92 & 0.837 & 10.2714 & 3.5248 & 0.007 & -6.00370 & 2.79400 & 0.040 & 0.783 & 0.47 \\
\hline $\mathrm{K}$ & Dietary K & 39 & 0.14 & 2.66 & 0.959 & 7.0293 & 3.0830 & 0.063 & & & & 1.639 & 0.85 \\
\hline $\mathrm{Cl}$ & Dietary Cl & 35 & -0.08 & 0.84 & 0.925 & 7.0545 & 0.5711 & $<0.001$ & & & & 0.961 & 0.91 \\
\hline
\end{tabular}

${ }^{1}$ Dietary cation-anion difference (DCAD), meq/100 g of DM; milk yield, kg/d; $4 \% \mathrm{FCM}, \mathrm{kg} / \mathrm{d}$; DMI, kg/d; blood $\mathrm{HCO}_{3}$, meq/L; blood $\mathrm{CO}_{2}$ partial pressure (blood pCO ${ }_{2}$ ), mm of $\mathrm{Hg}$; blood cation-anion difference (BCAD), meq/L; blood minerals ( $\mathrm{K}, \mathrm{Cl}, \mathrm{P}$, and $\mathrm{Mg}$ ), meq/L; dietary minerals $(\mathrm{Na}, \mathrm{K}, \mathrm{Cl}$, and $\mathrm{P}), \%$ of $\mathrm{DM}$; and urine minerals ( $\mathrm{Na}$, $\mathrm{K}$, and $\mathrm{Cl}$ ), urine mineral:creatinine ratio. 


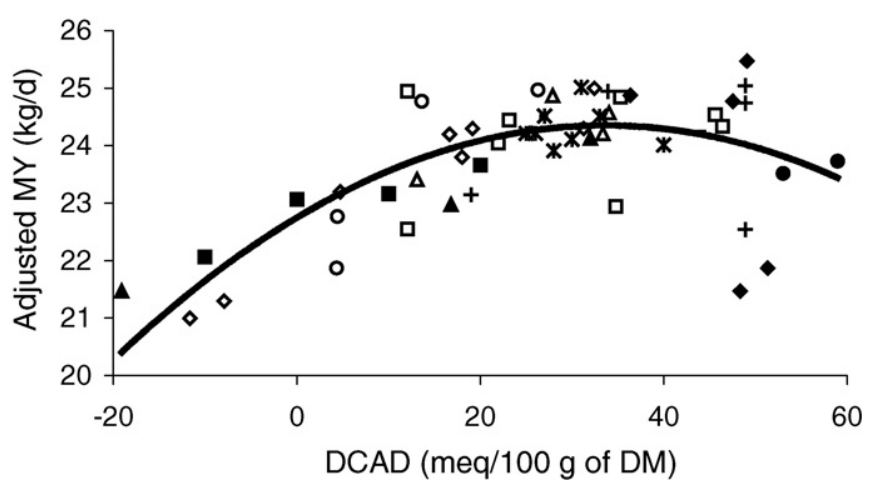

Figure 1. Relationship between dietary cation-anion difference (DCAD) and adjusted milk yield (MY) for studies reported in the literature. The adjusted MY $(\mathrm{kg} / \mathrm{d})=-0.00142 \times \mathrm{DCAD}^{2}(\mathrm{meq} / 100 \mathrm{~g}$ of $\mathrm{DM})+0.0955 \times \mathrm{DCAD}(\mathrm{meq} / 100 \mathrm{~g}$ of $\mathrm{DM})+22.75$; across studies, quadratic $P=0.002 ; \mathrm{R}^{2}=0.49 ; \mathrm{n}=54$. Legend: Delaquis and Block (1995a) ( ), Delaquis and Block (1995b) ( ), Escobosa et al. (1984) (ム), McKinnon et al. (1990) ( $\triangle$ ), Sanchez et al. (1997) (*), Tucker et al. (1988a) (匹), Tucker et al. (1991) (+), Tucker et al. (1994) (-), Waterman et al. (1991) (○), West et al. (1991) ( $\diamond)$, and West et al. (1992) ( $\square$ ).

BCAD (Table 4). Absorbed fixed ions (e.g., Na, K, and Cl) contribute positive and negative charges to the system, affecting electrical balance of the body. All body fluids must remain neutral electrically; therefore, changed electrical balance must affect acid-base status of the body. As BCAD increases, more bicarbonate ion must be generated and released into the system to maintain electroneutrality. As discussed above, it appears likely that DCAD affects blood $\mathrm{pH}$ via altering blood $\mathrm{HCO}_{3}$ concentration.

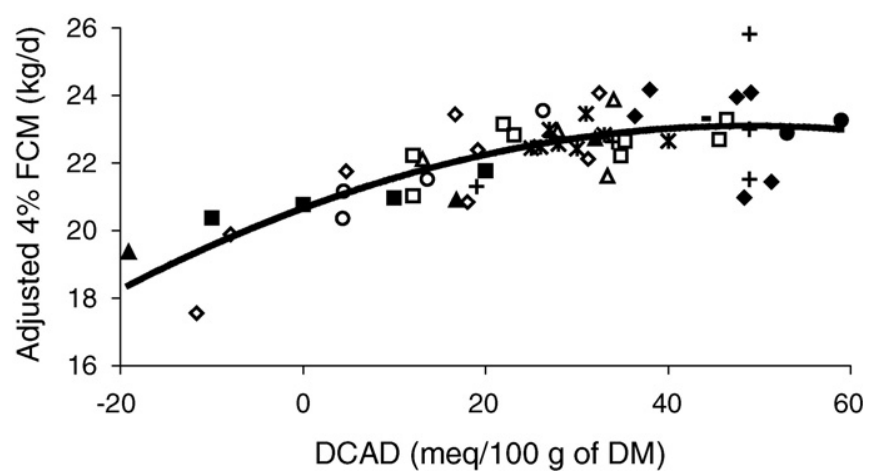

Figure 2. Relationship between dietary cation-anion difference (DCAD) and adjusted 4\% FCM for studies reported in the literature. The adjusted $4 \% \mathrm{FCM}(\mathrm{kg} / \mathrm{d})=-0.00102 \times \mathrm{DCAD}^{2}(\mathrm{meq} / 100 \mathrm{~g}$ of DM$)$ $+0.0998 \times \mathrm{DCAD}(\mathrm{meq} / 100 \mathrm{~g}$ of $\mathrm{DM})+20.66$; across studies, quadratic $P=0.029 ; \mathrm{R}^{2}=0.59 ; \mathrm{n}=54$. Legend: Delaquis and Block (1995a) $(\bullet)$, Delaquis and Block (1995b) ( ), Escobosa et al. (1984) (ム), McKinnon

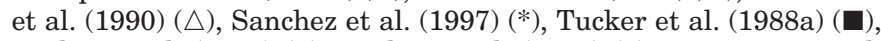
Tucker et al. (1991) (+), Tucker et al. (1994) (-), Waterman et al.

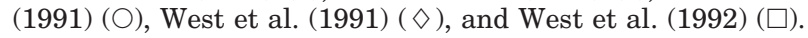

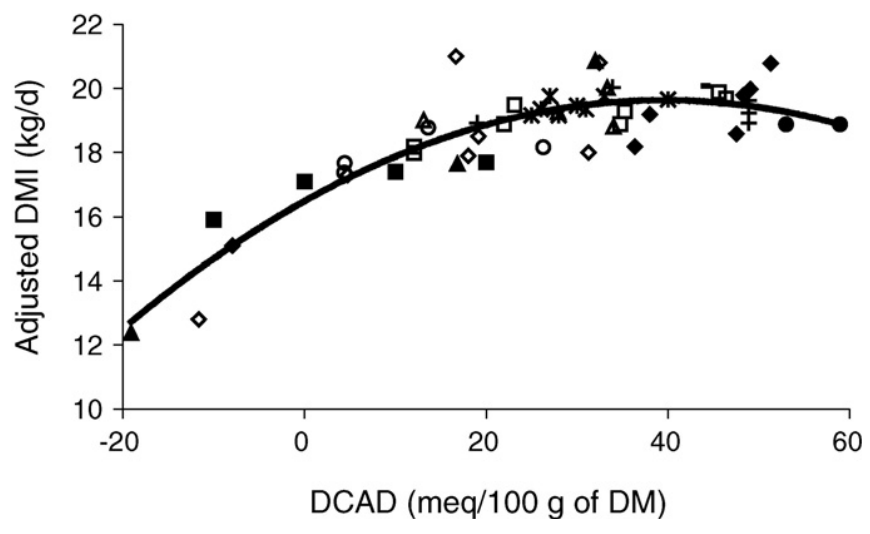

Figure 3. Relationship between dietary cation-anion difference (DCAD) and adjusted DMI from studies reported in the literature. The adjusted DMI $(\mathrm{kg} / \mathrm{d})=-0.00201 \times \mathrm{DCAD}^{2}(\mathrm{meq} / 100 \mathrm{~g}$ of $\mathrm{DM})+$ $0.1590 \times \mathrm{DCAD}(\mathrm{meq} / 100 \mathrm{~g}$ of $\mathrm{DM})+16.49$; across studies, quadratic $P<0.001 ; \mathrm{R}^{2}=0.80 ; \mathrm{n}=54$. Legend: Delaquis and Block (1995a) ( $)$, Delaquis and Block (1995b) ( ), Escobosa et al. (1984) (A), McKinnon

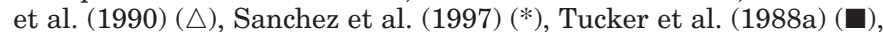
Tucker et al. (1991) (+), Tucker et al. (1994) (-), Waterman et al. (1991) (○), West et al. (1991) ( $\diamond)$, and West et al. (1992) $(\square)$.

Blood contents of $\mathrm{Na}$ and $\mathrm{K}$ were not altered by dietary $\mathrm{Na}$ and $\mathrm{K}$, respectively, even for diets containing high concentrations of these minerals. This was probably because excess $\mathrm{Na}$ and $\mathrm{K}$ were excreted via the kidney. Blood $\mathrm{Cl}$ content, on the other hand, increased linearly with dietary $\mathrm{Cl}\left(P<0.001, \mathrm{R}^{2}=0.37\right.$; Table 4$)$.

Blood content of $\mathrm{Na}$ was not affected by DCAD but blood $\mathrm{K}$ decreased linearly as DCAD increased $(P=$ $0.022, \mathrm{R}^{2}=0.26$; Table 4$)$. No explanation is readily

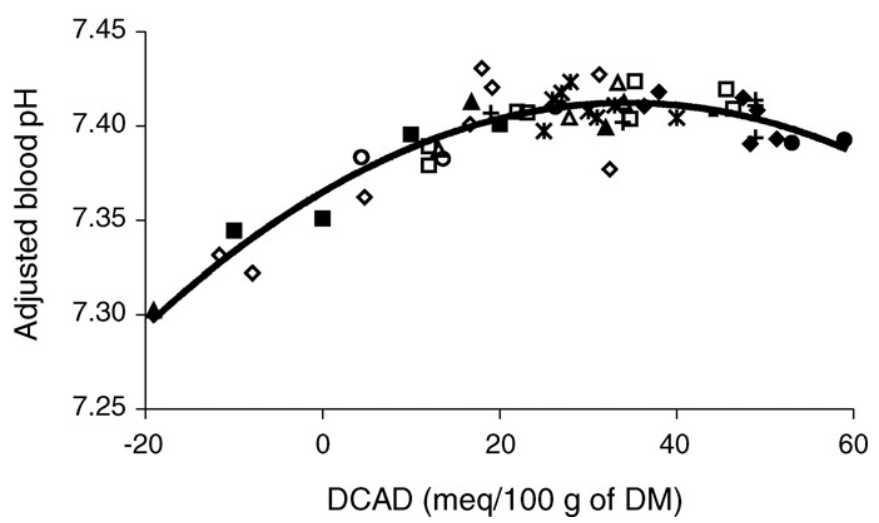

Figure 4. Relationship between dietary cation-anion difference (DCAD) and adjusted blood $\mathrm{pH}$ for studies reported in the literature. The adjusted blood $\mathrm{pH}=-0.00004 \times \mathrm{DCAD}^{2}(\mathrm{meq} / 100 \mathrm{~g}$ of $\mathrm{DM})+$ $0.0028 \times \mathrm{DCAD}(\mathrm{meq} / 100 \mathrm{~g}$ of $\mathrm{DM})+7.36$; across studies, quadratic $P<0.001 ; \mathrm{R}^{2}=0.83 ; \mathrm{n}=54$. Legend: Delaquis and Block (1995a) $(\bullet)$, Delaquis and Block (1995b) ( $\bullet$ ), Escobosa et al. (1984) (A), McKinnon

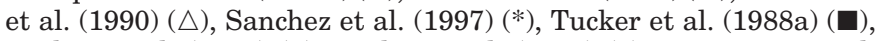
Tucker et al. (1991) (+), Tucker et al. (1994) (-), Waterman et al. $(1991)(\bigcirc)$, West et al. (1991) ( $\diamond)$, and West et al. (1992) $(\square)$. 


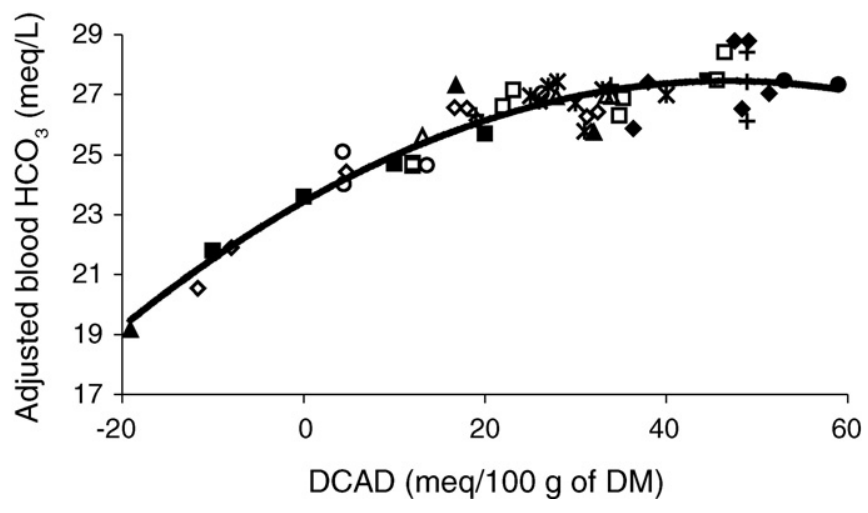

Figure 5. Relationship between dietary cation-anion difference (DCAD) and adjusted blood $\mathrm{HCO}_{3}$ from studies reported in the literature. The adjusted blood $\mathrm{HCO}_{3}(\mathrm{meq} / \mathrm{L})=-0.00184 \times \mathrm{DCAD}^{2}$ (meq/ $100 \mathrm{~g}$ of $\mathrm{DM})+0.1721 \times \mathrm{DCAD}(\mathrm{meq} / 100 \mathrm{~g}$ of $\mathrm{DM})+23.43$; across studies, quadratic $P<0.001 ; \mathrm{R}^{2}=0.88 ; \mathrm{n}=54$. Legend: Delaquis and Block (1995a) (-), Delaquis and Block (1995b) ( ), Escobosa et al.

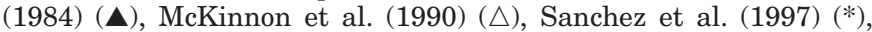
Tucker et al. (1988a) (ם), Tucker et al. (1991) (+), Tucker et al. (1994) $(-)$, Waterman et al. (1991) (○), West et al. (1991) $(\diamond)$, and West et al. (1992) ( $\square)$.

apparent for the latter result. Blood $\mathrm{Cl}$ decreased quadratically with increasing $\mathrm{DCAD}\left(P=0.032, \mathrm{R}^{2}=0.36\right.$; Table 4), presumably because of the inverse relationship between blood $\mathrm{Cl}$ and $\mathrm{HCO}_{3}$ concentrations. Of the 3 electrolytes analyzed, blood $\mathrm{Cl}$ was most affected by changes in dietary $\mathrm{Cl}$ content $\left(P<0.001, \mathrm{R}^{2}=0.37\right.$; Table 4) and DCAD. Tucker et al. (1988a) proposed that $\mathrm{Cl}$ might primarily be responsible for the altering the acid-base status of lactating dairy cows.

Blood Ca was not affected by its dietary concentrations or DCAD (Table 4). Prepartum DCAD dramatically affects $\mathrm{Ca}$ metabolism at parturition (Oetzel et al., 1988; Goff et al., 1991). Diets supplemented with anionic salts (i.e., low DCAD) alter Ca homeostasis and increase plasma $\mathrm{Ca}$ concentration at parturition. The present study found no evidence of a direct relationship between blood $\mathrm{Ca}$ concentration and DCAD postpartum.

\section{Urine $\mathrm{pH}$ and Minerals}

Urine $\mathrm{pH}$ was very responsive to changes in DCAD, quadratically increasing $\left(P<0.001 ; \mathrm{R}^{2}=0.86\right)$ with DCAD (Table 4; Figure 6) and peaking at 62 meq/100 $\mathrm{g}$ of DM. Increased urinary $\mathrm{pH}$ may be attributed to greater blood $\mathrm{HCO}_{3}$ and declining urine net acid excretion, implying that the acid load of lactating cows decreased dramatically as DCAD increased. Excretions of $\mathrm{K}$ and $\mathrm{Cl}$ [expressed as ratios of mineral concentration (in $\mathrm{mg} / \mathrm{L}$ ) to creatinine concentration (in $\mathrm{mg} / \mathrm{L}$ ) in the urine] increased linearly with their respective dietary

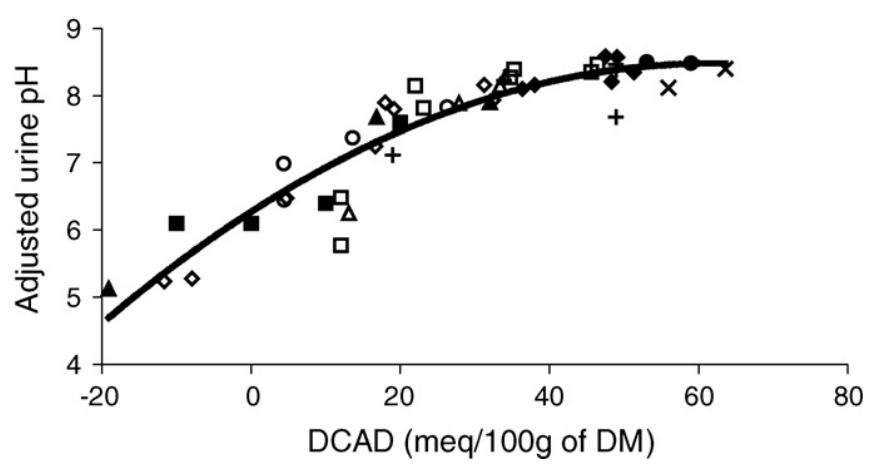

Figure 6. Relationship between dietary cation-anion difference (DCAD) and adjusted urine $\mathrm{pH}$ from studies reported in the literature. The adjusted urine $\mathrm{pH}=-0.00058 \times \mathrm{DCAD}^{2}($ meq/100 $\mathrm{g}$ of $\mathrm{DM})+$ $0.0716 \times \mathrm{DCAD}(\mathrm{meq} / 100 \mathrm{~g}$ of $\mathrm{DM})+6.27$; across studies, quadratic $P<0.001 ; \mathrm{R}^{2}=0.86 ; \mathrm{n}=46$. Legend: Delaquis and Block (1995a) $(\bullet)$, Delaquis and Block (1995b) ( ), Escobosa et al. (1984) (A), McKinnon

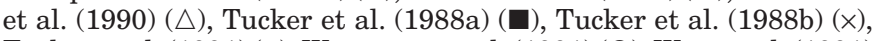
Tucker et al. (1991) (+), Waterman et al. (1991) (○), West et al. (1991) $(\diamond)$, and West et al. (1992) ( $\square)$.

concentrations, but excretion of $\mathrm{Na}$ changed quadratically with its dietary concentration (Table 4). These changes reflected small changes in blood mineral concentrations, especially $\mathrm{Na}$ and $\mathrm{K}$, resulting from dietary treatments.

\section{CONCLUSION}

Meta-analysis of available data suggested that DCAD affects the performance of lactating dairy cows. Milk yield and feed intake increased quadratically with DCAD up to 34 and $40 \mathrm{meq} / 100 \mathrm{~g}$ of DM, respectively. Blood $\mathrm{pH}$ and $\mathrm{HCO}_{3}$ also increased with $\mathrm{DCAD}$, peaking at 35 and $47 \mathrm{meq} / 100 \mathrm{~g}$ of DM, respectively, and indicating an improved acid-base status of the lactating cows. Changes in urinary $\mathrm{pH}$ and excretion of $\mathrm{Na}, \mathrm{K}$, and $\mathrm{Cl}$ were consistent with changes in DCAD. The effects of DCAD on DMI and milk yield were likely mediated via modification of acid-base physiology in the cows.

\section{REFERENCES}

Allen, M. S. 1997. Relationship between fermentation acid production in the rumen and the requirement for physically effective fiber. J. Dairy Sci. 80:1447-1462.

Austic, R. E., and J. F. Patience. 1988. Undetermined anion in poultry diets: Influence on acid-base balance, metabolism, and physiological performance. CRC Crit. Rev. Poult. Biol. 1:315-345.

Block, E. 1984. Manipulating dietary anions and cations for prepartum dairy cows to reduce incidence of milk fever. J. Dairy Sci. 67:2939-2948.

Block, E., and W. K. Sanchez. 2000. Is it important to adjust the dietary cation-anion difference for lactating dairy cows? Pages 27-39 in Proc. Tri-State Dairy Nutr. Conf., Fort Wayne, IN. Ohio State Univ., Columbus.

Delaquis, A. M., and E. Block. 1995a. The effects of changing ration ingredients on acid-base status, renal function, and macromineral metabolism. J. Dairy Sci. 78:2024-2039. 
Delaquis, A. M., and E. Block. 1995b. Dietary cation-anion difference, acid-base status, mineral metabolism, renal function, and milk production of lactating cows. J. Dairy Sci. 78:2259-2284.

Efron, B. 1982. The Jackknife, the Bootstrap and Other Resampling Plans. Soc. Industrial Appl. Math., Philadelphia, PA.

Escobosa, A., C. E. Coppock, L. D. Rowe, Jr., W. L. Jenkins, and C. E. Gates. 1984. Effects of dietary sodium bicarbonate and calcium chloride on physiological responses of lactating dairy cows in hot weather. J. Dairy Sci. 67:574-584.

Goff, J. P., R. L. Horst, F. J. Mueller, J. K. Miller, G. A. Kiess, and H. H. Dowlen. 1991. Addition of chloride to a prepartal diet high in cations increases 1,25-dihydroxyvitamin $\mathrm{D}$ response to hypocalcemia preventing milk fever. J. Dairy Sci. 74:3863-3871.

Huber, T. L. 1976. Physiological effects of acidosis on feedlot cattle. J. Anim. Sci. 43:902-909.

Kolver, E. S., and M. J. de Veth. 2002. Prediction of ruminal pH from pasture-based diets. J. Dairy Sci. 85:1255-1266.

McKinnon, J. J., D. A. Christensen, and B. Laarveld. 1990. The influence of bicarbonate buffers on milk production and acid-base balance in lactating dairy cows. Can. J. Anim. Sci. 70:875-886.

NRC. 2001. Nutrient Requirements of Dairy Cattle. 7th rev. ed. Natl. Acad. Sci., Washington, DC.

Oetzel, G. R., J. D. Olson, C. R. Curtis, and M. J. Fettman. 1988. Ammonium chloride and ammonium sulfate for prevention of parturient paresis in dairy cows. J. Dairy Sci. 71:3302-3309.

Roche, J. R., D. Dalley, P. Moate, C. Grainger, M. Rath, and F. O'Mara. 2003. Dietary cation-anion difference and the health and production of pasture-fed dairy cows. 1 . Dairy cows in early lactation. J. Dairy Sci. 86:970-978.

Sanchez, W. K., and D. K. Beede. 1996. Is there an optimal cationanion difference for lactation diets? Anim. Feed Sci. Technol. 59:3-12.

Sanchez, W. K., D. K. Beede, and J. A. Cornell. 1997. Dietary mixtures of sodium bicarbonate, sodium chloride, and potassium chloride: Effects on lactational performance, acid-base status, and mineral metabolism of Holstein cows. J. Dairy Sci. 80:1207-1216.
SAS ${ }^{\circledR}$ System Software: Release 8.2 (TS2M0), 2001. SAS Inst., Inc., Cary, NC.

St-Pierre, N. R. 2001. Invited review: Integrating quantitative findings from multiple studies using mixed model methodology. J. Dairy Sci. 84:741-755

Swenson, M. J. 1993. Physiological properties and cellular and chemical constituents of blood. Pages 22-48 in Duke's Physiology of Domestic Animals. 11th ed. M. J. Swenson and W. O. Reece, ed. Cornell Univ. Press, Ithaca, NY.

Tucker, W. B., G. A. Harrison, and R. W. Hemken. 1988a. Influence of dietary cation-anion balance on milk, blood, urine, and rumen fluid in lactating dairy cattle. J. Dairy Sci. 71:346-354.

Tucker, W. B., J. F. Hogue, D. F. Waterman, T. S. Swenson, Z. Xin, R. W. Hemken, J. A. Jackson, G. D. Adams, and L. J. Spicer. 1991. Role of sulfur and chloride in the dietary cation-anion balance equation for lactating dairy cattle. J. Anim. Sci. 69:1205-1213.

Tucker, W. B., I. S. Shin, J. F. Hogue, M. Aslam, G. D. Adams, M. T. Van Koevering, R. K. Vernon, and K. R. Cummings. 1994. Natural sodium sesquicarbonate fed for an entire lactation: Influence on performance and acid-base status of dairy cows. J. Dairy Sci. 77:3111-3117.

Tucker, W. B., Z. Xin, and R. W. Hemken. 1988b. Influence of dietary calcium chloride on adaptive changes in acid-base status and mineral metabolism in lactating dairy cows fed a diet high in sodium bicarbonate. J. Dairy Sci. 71:1587-1597.

Waterman, D. F., T. S. Swenson, W. B. Tucker, and R. W. Hemken. 1991. Role of magnesium in the dietary cation-anion balance equation for ruminants. J. Dairy Sci. 74:1866-1873.

West, J. W., K. D. Haydon, B. G. Mullinix, and T. G. Sandifer. 1992. Dietary cation-anion balance and cation source effects on production and acid-base status of heat-stressed cows. J. Dairy Sci. 75:2776-2786.

West, J. W., B. G. Mullinix, and T. G. Sandifer. 1991. Changing dietary electrolyte balance for dairy cows in cool and hot environments. J. Dairy Sci. 74:1662-1674. 